\title{
Diel activity of the tadpoles of Hyla hylax (Anura: Hylidae) at Boracéia, Southeastern Brazil
}

\author{
Jaime Bertoluci' \\ Departamento de Zoologia, Instituto de Biociências, Universidade de São Paulo. São Paulo. Brazil. \\ 1 Present Address: Departamento de Zoologia, Instituto de Ciências Biológicas, Universidade Federal de Minas \\ Gerais. Caixa Postal 486, Belo Horizonte, MG, Brazil. 31270-901. E-mail: bertoluc@icb.ufmg.br.
}

Behavioral ecological data on anuran larvae are critical to conservation practices because success of the larval phase strongly influences adult recruitment; anuran mortality is typically highest during the tadpole stage (Heyer, 1973, 1979; Crump, 1982). The larvae sometimes show ecological adaptations related to predation avoidance (Wassersug, 1971; Heyer et al., 1975), such as schooling behavior (Wild, 1996), and increased feeding and thermoregulation efficiency (Mullaly, 1953; De Vlaming and Bury, 1970; Beiswenger, 1975, 1977). Data on tadpole diel cycles are rare and derived mainly from laboratory observations on phototaxis. Usually, tadpoles are diurnal in warm ponds and nocturnal in cold streams (Duellman and Trueb, 1994), but Wild (1996) demonstrated that several Amazonian tadpoles are nocturnal in ponds. There are no data on Atlantic rainforest species. Herein, I present data on the diel activity of Hyla hylax tadpoles and their potential aquatic predators. These observations are based on diurnal and nocturnal samples taken in a forest stream of Boracéia, southeastern Brazil.

Hyla hylax is a medium-sized treefrog (10 males, 55-62 mm; 2 females, 60-63.4 mm SVL) included in the $H$. circumdata Group that inhabits the Atlantic rainforest of southeastern Brazil (Heyer, 1985; Heyer et al. 1990). Adult males call at night from the ground, bushes, bromeliad tubes at variable height, or rock crevices near forest streams (Heyer et al., 1990; pers. obs.). At Boracéia the breeding season of this species lasts from August to February (Bertoluci and Rodrigues, 2002). The repro-

Received 18.06.2001

Accepted 22.09.2001 ductive mode of $H$. hylax is unknown, but tadpoles are easily found in several small forest streams in the study site throughout the year (Bertoluci 1997; Figure 1).

Field work was carried out at the Boracéia Biological Station, a 16,450-ha Atlantic rainforest reserve in southeastern Brazil $\left(23^{\circ}\right.$ $\left.38^{\prime} \mathrm{S}, 45^{\circ} 52^{\prime} \mathrm{W}\right)$. Boracéia is situated within the Tropical Atlantic Morphoclimatic Domain (Ab'Saber, 1977) at about $900 \mathrm{~m}$ above sea level (see Heyer et al., 1990 for a map). Descriptions of several aspects of the local vegetation can be found in Travassos and Camargo (1958), Heyer et al. (1990), Wilms (1995) and Wilms et al. (1996). The average annual rainfall between 1973 and 1994 was $2024 \mathrm{~mm}$ and the mean temperature for the same period was $17.9^{\circ} \mathrm{C}$ (DAEE, 1994).

The anuran fauna of Boracéia is highly diverse and comprises 66 species belonging to the families Brachycephalidae (1 species), Bufonidae (3), Centrolenidae (2), Hylidae (29), Leptodactylidae (30), and Microhylidae (1) (Heyer et al., 1990; Bertoluci, 1997). By the late 1970 s, several population declines and local extinctions were detected at Boracéia (Heyer et al., 1988, 1990); the status of the fauna was updated by Bertoluci and Heyer (1995) and Bertoluci (1997).

In determining the diel activity cycle of Hyla hylax tadpoles, I assumed that the number of tadpoles captured in a trap is directly correlated to the degree of their activity. I sampled a small stream from October 11 to October 14, 1995, using double-entry funneltraps constructed with 2-1 plastic bottles $(10 \mathrm{~cm}$ diameter and $33 \mathrm{~cm}$ long). The stream consisted of interconnected puddles with rocky or sandy bottoms covered with dead leaves and sticks. 
The study plot was $60 \mathrm{~m}$ long, $1.3 \mathrm{~m}$ wide, and had a maximum depth of $22 \mathrm{~cm}$. Ten diurnal (0600-1800h) and ten nocturnal (1800-0600h) samples were obtained from the same puddles. The diurnal sampling was initiated 24 hours after the end of the previous nocturnal sampling. Unbaited traps were positioned on the stream bed because Hyla hylax tadpoles are benthic (pers. obs.). Potential tadpole predators (larval Odonata, Coleoptera and larval and adult Heteroptera) were captured in the same traps. Voucher specimens were deposited in the herpetological collection of the Universidade Federal de Minas Gerais (UFMG). Voucher specimens of the invertebrates were deposited in the entomological collection of Museu de Zoologia da USP. In order to test if there was a diference between the numbers of tadpoles captured during each period, I performed a Student's $t$-test with variances separately estimated for heterocedasticity (Zar, 1984).

A total of 29 tadpoles of Hyla hylax and 33 individual potential predators was captured in the traps at night. Only four tadpoles and no predators were captured by day. There was a significant difference between the numbers of tadpoles captured in each period ( $t$ for separate variances $=2.98 ; \mathrm{df}=10 ; P$-value 0.013$)($ Figure 2).

The predominantly nocturnal activity of Hyla hylax tadpoles corroborates the observations made in Crossodactylus dispar (Bokermann, 1963), Ascaphus truei (DeVlaming and Bury, 1970), Hyla nanuzae, a species also included in the Hyla circumdata Group (Bokermann and Sazima, 1973), along with several species of Hyla, Plectrohyla, Ptychohyla, and Telmatobius tadpoles developing in cold streams (Duellman and Trueb, 1994). Because the water temperature in the stream varies little between day and night year-round (pers. obs.), this pattern probably is not related to an increase of feeding or thermoregulation efficiency. Instead, the nocturnal activity of these tadpoles may represents an adaptation to avoid diurnal, visually oriented predators (e.g., birds). My data reveal that tadpole predators in that streams also are more active by night. It seems likely that the tadpoles might depend on their disruptive coloration as camouflage, as suggested by Altig and Channing (1993); moreover their highly developed tail musculature suggests that they may use swimming speed to minimize predation. Further data are needed to determine diel cycles of tadpoles in different habitats and their significance to larval survivorship.

\section{Ackowledgements}

I thank Miguel Trefaut Rodrigues and W. Ronald Heyer for advice. Thanks also are due to Cybele Araujo, Vinícius Xavier, Tereza Orlando, and Regina C. Vincent for help in the field; Adriano Paglia helped with the statistics. Support for this work was provided by Museu de Zoologia da USP, CAPES, and FAPESP (Processo 96/6701-3).

\section{References}

Ab'Saber, A. N. 1977. Os domínios morfo-climáticos na América do Sul. Primeira aproximação. Geomorfologia 52: 1-22.

Altig, R. and A. Channing. 1993. Hypothesis: functional significance of color and pattern in anuran tadpoles. Herpetological Journal 3: 73-75.

Beiswenger, R. E. 1975. Structure and function in aggregation of tadpoles of the American toad, Bufo americanus. Herpetologica 31: 222-233.

Beiswenger, R. E. 1977. Diel patterns of aggregative behavior in tadpoles of Bufo americanus in relation to light and temperature. Ecology 58: 98-108.

Bertoluci, J. A. 1997. Fenologia e seleção de hábitat em girinos da Mata Atlântica em Boracéia, Sāo Paulo (Amphibia, Anura). Unpublished Ph.D. Thesis, Instituto de Biociências. Universidade de São Paulo. Brazil.

Bertoluci, J. and W. R. Heyer. 1995. Boracéia update. Froglog 14: 2-3 (Newsletter of the World Conservation Union, Species Survival Comission, Declining Amphibian Populations Task Force). Open University, Wilton Hall, Milton Keynes, UK.

Bertoluci, J. and M. T. Rodrigues. In press. Seasonal patterns of breeding activity of Atlantic rainforest anurans at Boracéia, Southeastern Brazil. AmphibiaReptilia.

Bokermann, W. C. A. 1963. Girinos de anfibios brasileiros - 2. (Amphibia, Salientia). Revista Brasileira de Biologia $23: 349-353$.

Bokermann, W. C. A. and I. Sazima. 1973. Anfíbios da Serra do Cipó, Minas Gerais, Brasil. I - Espécies novas de "Hyla" (Anura, Hylidae). Revista Brasileira de Biologia 33: 329-336.

Crump, M. L. 1982. Amphibian reproductive ecology on the community level. U.S. Fish and Wildlife Resource Report 13: 21-36. 

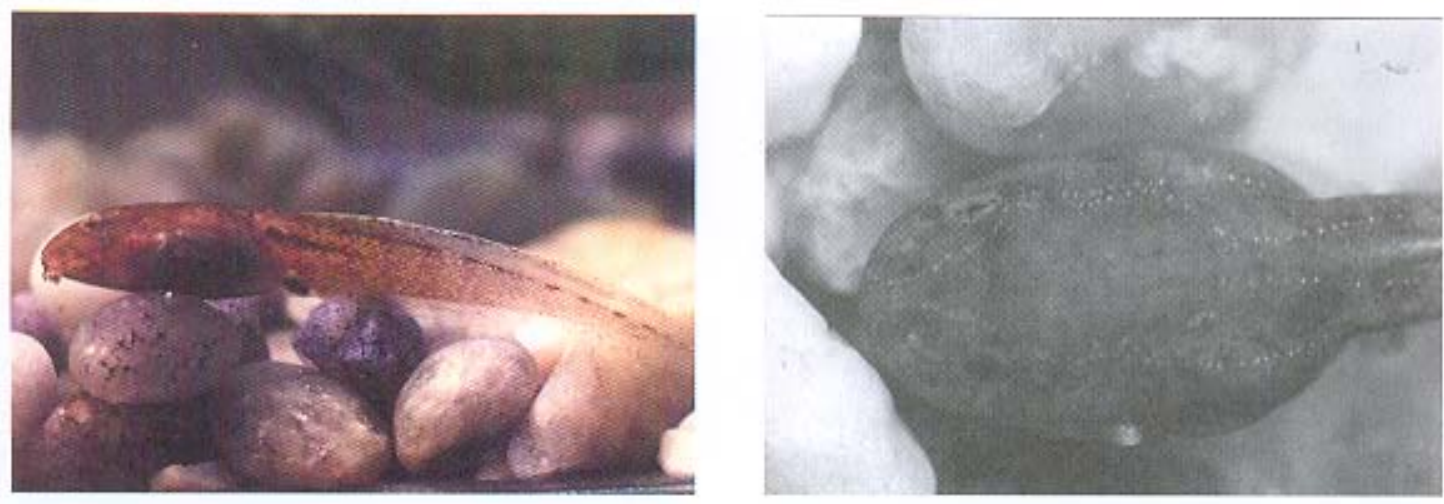

Figure 1- Tadpole of Hyla hylox from Boracéia, Southeastern Brazil, in lateral (a) and dorsal (b) views.

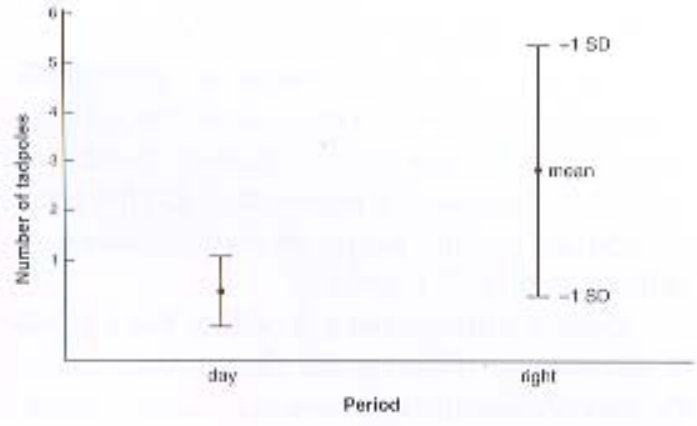

Figure 2 - Mean ( \pm SD) number of tadpoles trapped in 10 funnel-traps during the day $(0600-1800)$ and during the night (1800-0600) in a forest stream at Boracéia, Southeastern Brazil.

DAEE (Departamento de Águas e Energia Elétrica do Estado de São Paulo). 1994. Lay-out dos registros diários de temperatura e precipitação. Sāo Paulo.

De Vlaming, V. L. and R. P. Bury. 1970. Thermal selection in tadpoles of the tailed-frog, Ascaphis stwer. Journat of Herpetology \&: 179-189,

Duellman, W. E. and 1. Trucb. 1994, Biology of Amphibians. The Johns Hopkins University Press. Baltimore and London.

Heyer, W. R. 1973. Ecological interactions of frog larvae at a seasonal tropical location in Thailand, Journal of Herpetology 7: 337-361.

Heyer, W. R, 1979. Annual variation in larval amphibian populations within a temperate pond. Journal of the Wasington Academy of Sciences 69: 65-74.

Heyer, W. R. 1985. New species of frogs from Boracéia,
São Paulo, Brazil. Proceedings of the Biological Society of Washingson 98: 657-677

Heyer, W. R., R. W. McDiarmid, and D. L. Weigmann. 1975. Tadpoles, predation and pond habitats in the tropics. Biotropica 7: 100-111.

Heyer, W. R., A. S. Rand, C. A. G. Cruz, and O. L., Peixoto. 1988. Devimations, extinctions, and colonizations of frog populations in southeast Brazil and their cvolutionary implications, Biofropica 20: 230-235.

Hever, W. R., A. S. Rand, C. A. G. Cruz, O. L. Peixoto, and C. E. Nelson. 1990. Frogs of Boracéia. Arquivos de Zoología, São Paulo 31: 231-410.

Mullaly, D. P. 1953. Observations on the ceology of the toad, Bufo conorrs. Copeia 1953: 182-183.

Travassos, L. and H. F. A. Camargo. 1958. A Estaçāo Biológica de Boracéia. Arquivos de Zoologia, Sao Pauio II: $1-21$.

Wassersug, R. J. 1971. On the comparative palatability of some dry seasen tadpoles from Costa Rica. American Midíand Naturalist 86: 101-109.

Wild, E. R. 1996. Natural history and resource use of four Amazonian tadpole assemblages. Occasional Papers of the Musew of Natural Histony of the University of Kansas 176: 1-59.

Wilms, W. 1995, Die Bienenfauna in Küstenregenwaid Brasiliens and thre Bezielangen zu Biutenpfianzen: Falisiadie Boracéia, São Paulo. Unpubi. Ph.D. Thesis. Fakultät für Biologie der Ebcrhard-KarlsUniversitiit Tübingen, Germany.

Wilms, W., V. Imperatriz-Fonseca, and W. Engels, 1996. Resource partitioning between highly cusocial bees and possible impact of the introduced africanized honey bee on native stingless bees in the Brazilian Atlantic Rainforest. Studies on Neotropical Fauna and Enwirongent 31: 137-151.

Zar, J. H, 1984. Biosiasistical Analysis. Prentice-Hall, Englewood Cliffs, New Jersey. 